\title{
THE ROLE OF E2/P RATIO IN THE ETIOLOGY OF FIBROCYSTIC BREAST DISEASE, MASTALGIA AND MASTODYNIA
}

\author{
Milena Brkić ${ }^{1}$, Svetlana Vujović ${ }^{2}$ Miomira Ivović ${ }^{2}$ Milina Tančić Gajić \\ Ljiljana Marina ${ }^{2}$, Maja Franić Ivanišević ${ }^{3}$ and Damir Franić c $^{4,5}$ \\ ${ }^{1}$ Medical Faculty, University of Banja Luka, Banja Luka, Bosnia and Herzegovina; \\ ${ }^{2}$ Department of Endocrinology, Clinical Center of Serbia, School of Medicine, University of Belgrade, \\ Belgrade, Serbia; ${ }^{3}$ Department of Gynecology and Obstetrics, Clinical Center of Serbia, Belgrade, Serbia; \\ ${ }^{4}$ Outpatient Clinic of Obstetrics and Gynecology, Rogaška Slatina, Slovenia; \\ ${ }^{5}$ School of Medicine, University of Maribor, Maribor, Slovenia
}

\begin{abstract}
SUMMARY - The aim of the study was to assess the role of the estradiol and progesterone relationship during the late luteal phase and the occurrence of fibrocystic breast disease (FBD). The concentration of estradiol/progesterone was measured in the group of women with FBD as study group $(n=50)$ and control group of women without FBD $(n=40)$. All women had regular ovulation cycles. Blood samples for estradiol (E2), progesterone $(\mathrm{P})$ and prolactin determination were obtained in the morning at 8 am on days 21 and 24 of menstrual cycle. Significant mastalgia and mastodynia history in women with FBD was obtained with yes or no questionnaire. FBD diagnosis was confirmed with ultrasound (size and number of simple cysts). In the control group, a reduced E2/P ratio was noticed from day 21 to day 24 of the cycle (from $14.8 \pm 11.5 \mathrm{pg} / \mathrm{mL}$ to $9.1 \pm 6.1 \mathrm{pg} / \mathrm{mL} ; \mathrm{p}<0.05$ ), which was not recorded in the group of women with FBD (study group). Even the slightest disturbance of the $\mathrm{E} 2 / \mathrm{P}$ ratio may contribute to the occurrence of FBD with clinical manifestations of mastalgia and mastodynia.
\end{abstract}

Key words: Estradiol; Progesterone; Fibrocystic breast disease; Luteal phase

\section{Introduction}

Fibrocystic breast disease (FBD), recently called fibrocystic changes in the literature, is the most frequent benign breast disease, which is diagnosed in $50 \%$ of the clinically and $90 \%$ of the histopathologically examined women ${ }^{1}$. Its highest incidence is between 20 and 50 years of age, when a woman is most exposed to stress periods, e.g., her development in the society, forming a family and giving birth. In this period, her body is exposed to quite significant hormone turbulences ${ }^{2-4}$.

Correspondence to: Damir Franić, MD, Ginekologija dr. Franić d.o.o., Celjska c. 10, 3250 Rogaška Slatina, Slovenia

E-mail: damir.franic@guest.arnes.si

Received June 6, 2016, accepted August 23, 2016
The question is what causes the high incidence of these changes and how to ease the discomfort. The treatment is still just empirical, which leads the scientists to search for the pathophysiological cause of the changes and estimate the malignant potential. It is noted that, even in women with healthy hygienic-diet regimen and no risk habits such as excessive consumption of coffee, opiates and smoking, the disease is still manifested.

Many researchers believe that changes in hormone status of prolactin, thyroid hormones and steroid ovary hormones may lead to development of benign changes in the breasts ${ }^{4}$. Although some studies show how the prevalence of increased estrogen concentration during the menstrual cycle (MC) could be one of the main pathophysiological disorders ${ }^{5}$, there are controversies 
found in the literature. These controversies emphasize the absence of negative correlation between steroid ovary hormones and the occurrence of benign diseases of the breasts ${ }^{6,7}$.

So far, very few studies monitored the relation of sexual ovary hormones in the late luteal phase, most often in the first 7 days after ovulation.

Regarding the incidence, suffering and fear caused by benign changes in the breasts, studying secretion of just these hormones in the late $\mathrm{MC}$ secretion phase seemed to be quite important. The study was aimed at assessing the correlation between the hormones and the disease, in order to alleviate discomfort with appropriate therapy and improve emotional stability of the woman.

\section{Patients and Methods}

The study was conducted at the Department of Endocrinology, Clinical Center Serbia, and included 90 women with regular MC, aged 20 to 40 years, with normal body mass index (BMI) and waist/hip (W/H) ratio. Experimental group included 50 women with respective history data and clinical findings, existence of mastalgia and mastodynia, and premenstrual syndrome (PMS). Ultrasound (US) examination showed simple cysts sized $<1 \mathrm{~cm}$ in both breasts. Control group consisted of 40 healthy women without discomforts and PMS, and with regular clinical and US findings of the breasts.

At the beginning of the MC follicular phase, all women underwent hormone status testing on empty stomach for thyroid hormones, gonadotropic hormones, prolactin (PRL), ovarian steroid hormones and adrenal gland, insulin and biochemical analyses (glucose, urea, creatinine, cholesterol, triglycerides, liver transaminases, plasma iontophoresis). During the MC luteal phase, on days 21 and 24, blood samples were obtained from both groups of subjects for estrogen (E2), progesterone (P) and prolactin (PRL) determination. Hormone analysis was performed on a Roche immunoassay analyzer (modular analytics E170) by electrochemiluminescence using the immunoassay method (ECLIA). The Elecsys 2010 immunoassay, reagent kit 03000079122 was used for estrogen, Elecsys 2010 immunoassay, reagent kit 12145383122 for progesterone and Elecsys 2010 immunoassay, reagent kit 0320309319 for prolactin measurement.
Linear multifunction large resolution linear probe 4.2-12 MHz, $38 \mathrm{~mm}$, on a Loqic $5 \mathrm{GE}$ device was employed for breast US examination. The study excluded pregnant women and those with any kind of malignant disease, endocrinopathy, complex dysplastic cysts, fibroadenoma, as well as those who were using or had used birth control therapy.

History data were obtained by use of questionnaires with yes/no answers on MC regularity, PMS, giving birth and number of births, existence of discomfort in the breasts in the previous six months (tension, pain, discharge, nodularity), use of birth control therapy, FBD in the family, consumption of coffee and cigarettes, as well as healthy hygienic-diet regimen.

The study was conducted according to ethical principles and was approved by the Ethics Committee of the School of Medicine, University of Belgrade (no. 29/XI-8, 2012).

\section{Results}

Estrogen concentration measured on day 21 was not statistically different between the two groups $(\mathrm{p}=0.7999)$. Within the control group, there was a statistically significant drop of E2 from day 21 to day 24 (from $157.58 \pm 79.39 \mathrm{pg} / \mathrm{mL}$ to $124.89 \pm 52.34 \mathrm{pg} / \mathrm{mL}$; $\mathrm{p}=0.010)$ (Fig. 1).

Progesterone concentration on day 21 of the cycle was not statistically significantly different between the two groups of women ( $p=0.116)$, which confirmed the

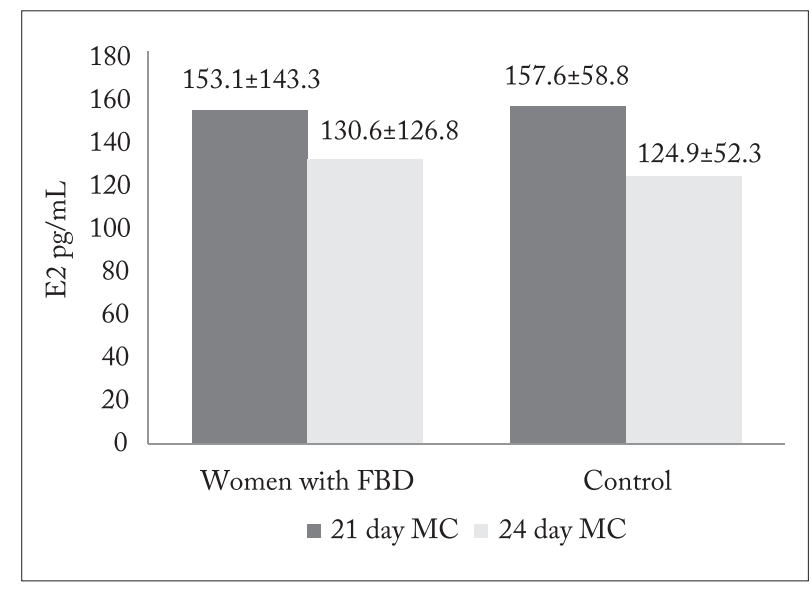

Fig. 1. Estradiol concentration on day 21 and 24 of the luteal phase.

$\mathrm{E} 2=$ estradiol; $\mathrm{FBD}=$ fibrocystic breast disease $; \mathrm{MC}=$ menstrual cycle 


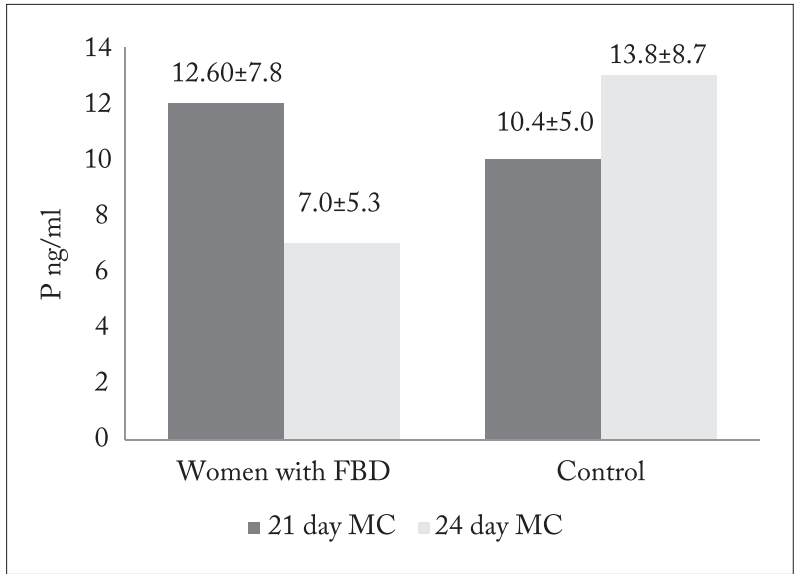

Fig. 2. Progesterone concentration on day 21 and 24 of the luteal phase.

$\mathrm{P}=$ progesterone; $\mathrm{FBD}=$ fibrocystic breast disease $\mathrm{MC}=$ menstrual cycle

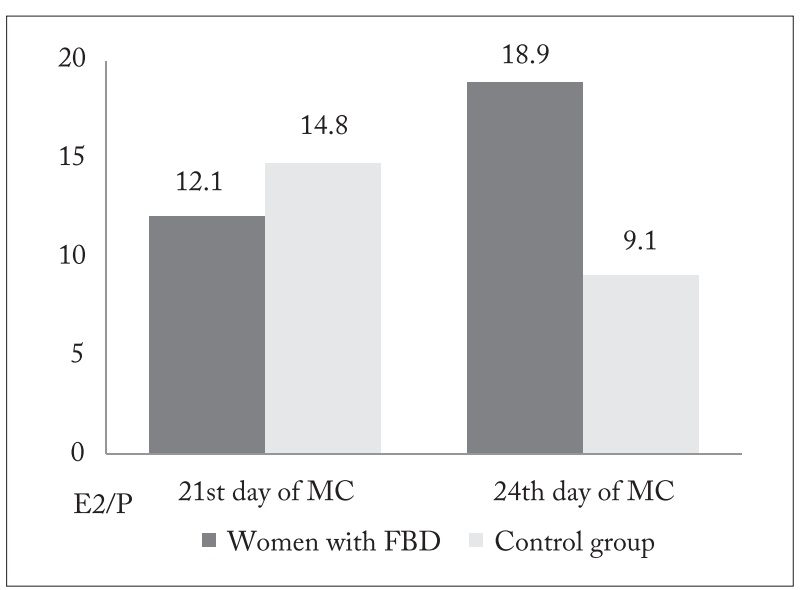

Fig. 3. E2/P ratio in late luteal phase.

$\mathrm{E} 2 / \mathrm{P}$ ratio = estradiol/progesterone ratio; $\mathrm{MC}=$ menstrual cycle; $\mathrm{FBD}=$ fibrocystic breast disease

ovulatory cycle. Progesterone concentration within the control group was higher on day 24 relative to day 21 (from $13.79 \pm 8.66 \mathrm{ng} / \mathrm{mL}$ to $10.36 \pm 6.92 \mathrm{ng} / \mathrm{mL}$; $\mathrm{p}<0.001$ ) (Fig. 2).

In control group, the $\mathrm{E} 2 / \mathrm{P}$ ratio on day 24 was $9.1 \pm 6.1$, which was a significant decrease from day 21 , when it was $14.8 \pm 11.1$, whereas in the group of FBD women it increased significantly from day 21 to day 24 of the cycle (from 12.1 $\pm 10.7: 18.9 \pm 23.8$ ) (Fig. 3).

In FBD women, the level of estrogen and progesterone deficiency in plasma on day 24 of MC caused a statistically significant incidence of tension and pain $(\mathrm{p}<0.05)$ (Fig. 4).

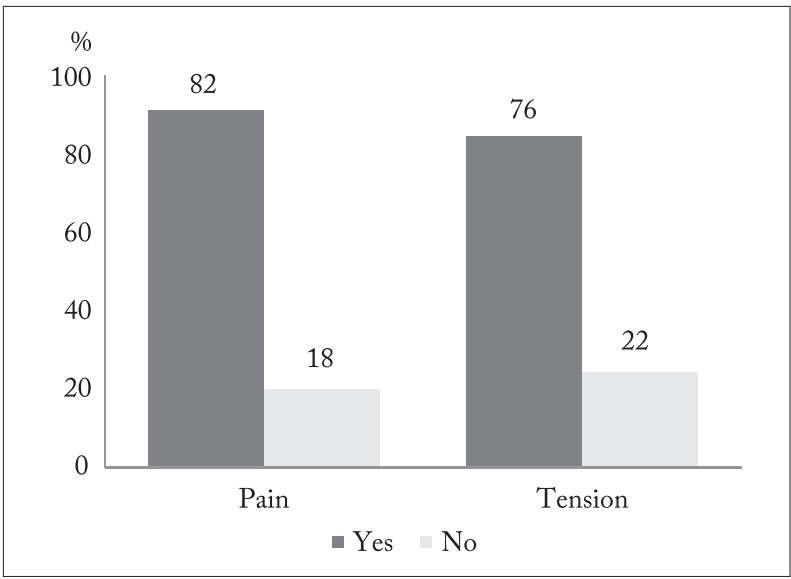

Fig. 4. Pain and tension during luteal phase in women with fibrocystic breast disease.

Tension and pain in the breasts were recorded in two women from the control group, however, it was of no statistical significance.

\section{Discussion}

Fibrocystic breast disease is the most common breast disease in gynecologic and radio-oncologic practice. The most often manifested discomforts are pain and tension in the breasts and tender nodes palpable in the breasts. The discomfort causes fear in women and interferes with their daily activities. The increasing incidence of this disease may be influenced by age, obesity, smoking, hormone preparations, PMS, stress, ductectasia, and alcohol and caffeine consumption $^{8}$.

However, in the absence of the abovementioned potential risk factors, the question is what other risk factors may influence the pathophysiological process of this disease, and whether imbalance of female sexual hormones, responsible for development of female breasts, can lead to manifestation of this disease.

Some researchers state that disturbance of estrogen and progesterone plays an important role in this problem development ${ }^{9,10}$. Hormonal imbalance may be the consequence of changes in the concentration of steroid receptors and their affinity for estradiol and progesterone $^{11}$. Under the influence of estrogen, interlobular connective tissue collects mucosal edema, which then leads to its swelling and hyalinization. All this dynamics could influence the manifestation of mastopathy 
and sclero-cystic changes. Estrogen at the breast cell level enhances the synthesis of DNA, mitotic activity, differentiation and proliferation of breast cells and connective tissue ${ }^{12,13}$.

What happens with the breast epithelium during the $\mathrm{MC}$ secretion phase when a gradual decrease in the estrogen concentration is naturally expected, with a significant rise and maintenance of the progesterone concentration? The question is why this sequence is missing even when the lack of progesterone is recorded. While estrogen gives the main impulse to the mammary gland proliferation, the progesterone effect is the subject of discussion. Progesterone has a positive, modest or no influence, or may even inhibit cell growth. The researchers have found that cell proliferation directly depends on the estrogen-progesterone ratio in the breast tissue and that it is lower in the luteal than in the follicular phase ${ }^{14}$. In the breast tissue obtained by aspirate biopsy, it was found that a normal increase of progesterone in the luteal phase resulted in a decrease of the estrogen receptor but not progesterone receptor regulation ${ }^{15}$. Within the normal epithelial cell culture of human breast, researchers have noticed the inhibitory effect on cell proliferation due to long-lasting progesterone treatment (7 days) in the presence or absence of estrogen. Also, the cells showed proliferation growth after E2 treatment and returned to the inactive state when $\mathrm{P}$ was added ${ }^{16}$.

The women with high estrogen relative to progesterone (low E2/P ratio) face a higher possibility of developing an atypical benign breast disease with an increased risk of breast cancer ${ }^{7}$. Low endogenous level of luteal progesterone in peri-menopausal women correlates with an increased risk of breast cancer ${ }^{17}$.

High level of androgen, either from ovaries or suprarenal glands, showed antagonistic effect on progesterone, which influenced FBD development, and receptor gene polymorphism, which might result in benign mastopathy and breast cancer ${ }^{18}$. Recent reports show that higher concentrations of medroxyprogesterone acetate (MPA) resulted in the inhibition of proliferation under the influence of estrogen.

Rohan et al. tested the effect of conjugated equine estrogen (CEE) $0.625 \mathrm{mg} /$ day as a risk for the occurrence of benign proliferative breast disease $(\mathrm{BPBD})$ in the Women's Health Initiative (WHI), a randomized controlled study that included 10,739 women. There were a total of 232 newly diagnosed women with
BPBD established during the study (the women were monitored for a mean of 6.9 years). The CEE use was connected with a twice higher risk of BPBD (HR-2, $11,95 \% \mathrm{CI}=1.58-2.81)^{19}$. This led to a conclusion that there was a very important correlation between hyperestrogenemia and etiology of BPBD and that longterm breast exposure to higher estradiol concentration (7 years and more) should be the cause of BPBD development.

Guided by these considerations about E2 level as one of the BPBD causes and knowing that women in reproductive age have the highest estradiol concentration in plasma, we tested our patients exactly during this period of life.

Daily monitoring of E2/P changes during the luteal phase was needed for understanding the FBD pathophysiology. A single sample of E2/P on day 21 was not sufficient for monitoring its influence on the occurrence of cystic breast changes.

Our results showed that in FBD patients, there was a significant decrease in progesterone concentration in plasma on day 24 of MC and increase in estrogen concentration. We postulate that it is just the maintenance of constant hyperestrogenemia and reduced antagonistic anti-proliferation effect of the progesterone during the entire late luteal phase of MC that lead to the manifestation of discomfort and clinical findings in the breasts of women with FBD.

We found no correlation between BMI and FBD, which is in line with the report by Friedenreich et al. ${ }^{8}$. All our patients had normal BMI range. On the contrary, Baer et al. found positive correlation between $\mathrm{BMI}$ and percentage of BPBD development in the women of reproductive age. The women with normal BMI $\left(<25 \mathrm{~kg} / \mathrm{m}^{2}\right)$ had by $30 \%$ less risk of $\mathrm{BPBD}^{20}$. Current knowledge indicates that obesity and excessive body fat represent the grounds for production of higher estradiol and estriol (product of estradiol transformation). This means that higher BMI could influence (indirectly via hyperestrogenemia) the development of FBD.

To assess the role of prolactin in the pathogenesis of benign breast diseases, Sitruk-Ware et al. measured serum prolactin level before and during the thyrotropin releasing hormone (TRH) test in patients during the luteal phase. They measured serum level of $\mathrm{E}$ and $\mathrm{P}$ before and during 3 months of treatment with synthetic progesterone, lynestrenol. There was no signifi- 
cant difference in the basic secretion of prolactin before and during therapy, or after TRH injection between patients on therapy and control group ${ }^{21}$. In their study, Walsh et al. found increased prolactin and estradiol concentration in the second half of the luteal phase in women with benign breast disease in comparison with control group ${ }^{22}$. Correlation between prolactin level and FBD could not be found in our study, since all patients had normal prolactin levels.

During the lifespan, every woman sometimes feels cyclic pain, being most expressed in the second phase of $\mathrm{MC}$ and related to the increased intake of sweets, coffee and cigarettes with changes in hormone concentrations ${ }^{23}$. Ayers and Gidwani monitored hormonal changes in the group of women with mastodynia and recorded a significantly lower progesterone in the luteal phase and increased prolactin sensitive to thyrotropin releasing hormone in control group ${ }^{24}$.

However, there are other opinions. Thus, in the study that monitored mastalgia in patients 4 to 8 days after ovulation, there was no correlation of dynamic changes with E2/P ratio, hyperprolactinemia and PMS in women with $\mathrm{FBD}^{25}$.

We consider that it is important to test progesterone concentration in the first or second week after ovulation. The low progesterone concentration in the late luteal phase was the cause of mastodynia, mastalgia and PMS in our subjects with FBD.

\section{Conclusion}

Normal function of breast cells and tissue depends on an adequate share of estradiol and progesterone concentration. Even the slightest disturbance of the $\mathrm{E} 2 / \mathrm{P}$ ratio may contribute to the occurrence of $\mathrm{FBD}$ with clinical manifestations of mastalgia and mastodynia, and its correction may improve the quality of life, reduce the frequency of surgical treatments and eventually, the potential risk of developing breast carcinoma.

\section{References}

1. Milosevic ZC, Nadrljanski MM, Milovanovic ZM, Gusic NZ, Vucicevic SS, Radulovic OS. Breast dynamic contrast enhanced MRI: fibrocystic changes presenting as a non-mass enhancement mimicking malignancy. Radiol Oncol. 2017;51(2):130-6. doi: 10.1515/raon-2017-0016
2. Bartow SA, Pathak DR, Black WC, et al. Prevalence of benign, atypical, and malignant breast lesions in populations at different risk for breast cancer. A forensic autopsy study. Cancer. 1987;60:2751-60. doi.org/10.1002/1090142(19871201)60:11 <2751::AID-CNCR2820601127>3.0.CO;2-M

3. Sarnelli R, Squartini F. Fibrocystic condition and 'at risk' lesions in asymptomatic breasts: a morphologic study of postmenopausal women. Clin Exp Obstet Gynecol. 1991;18:271-9. PMID:1790612

4. Guray M, Sahin A. Benign breast diseases: classification, diagnosis, and management. Oncologist. 2006;11(5):435-49. doi: 10.1634/theoncologist.11-5-435

5. Vorherr H. Fibrocystic breast disease: pathophysiology, pathomorphology, clinical picture, and management. Am J Obstet Gynecol. 1986;154:161-79. PMID: 3511705

6. Walsh PV, Bulbrook RD, Stell PM, Wang DY, McDicken IW, George WD. Serum progesterone concentration during the luteal phase in women with benign breast disease. Eur J Cancer Clin Oncol. 1984;20(11):1339-43. doi: 10.1016/02775379(84)90052-X

7. Sitruk-Ware LR, Sterkers N, Mowszowicz I, Mauvais-Jarvis P. Inadequate corpus luteal function in women with benign breast diseases. J Clin Endocrinol Metab. 1977;44(4):771-4. doi: http://dx.doi.org/10.1210/jcem-44-4-771

8. Friedenreich CM, Bryant HE, Alexander F, Hugh J, Page DL. Risk factors for benign proliferative breast disease. Int J Epidemiol. 2000;29(4):4637-64. PMID:10922339

9. Andreeva EN, Rozhkova NI. Efficacy of micronized progesterone-containing transdermal gel in the treatment of fibrocystic mastopathy: results of a Russian study. RusOMJ Obstet Gynecol. 2016;12:131-6. doi: https://dx.doi.org/10.18565/aig.2016.12.131-6

10. Андреева ЕН, Леднева ЕВ. Основные аспекты этиологии и патогенеза фиброзно-кистозной болезни молочной железы. Акушерство и гинекология. 2002;6:C7-9.

11. Roszkowski PI, Hyc A, Stopińska-Głuszak U, Malejczyk J. Natural killer cell activity and sex hormone levels in mastopathy. Gynecol Endocrinol. 1997 Dec;11(6):399-404. PMID: 9476089

12. Welsch MJ, McManus TJ, Haviland SE, Dombroske EL, Swim S, Sharpe S, Conley E. Hormone regulation of DNA synthesis of normal and hyperplastic breast tissues in vitro and in vivo. In: Angeli A, et al., editors. Endocrinology of Cystic Breast Disease. New York: Raven Press, 1983; p. 47-58.

13. Branchini G, Schneider L, Cericatto R, Capp E, Brum IS. Progesterone receptors $\mathrm{A}$ and $\mathrm{B}$ and estrogen receptor alpha expression in normal breast tissue and fibroadenomas. Endocrine. 2009;35(3):459-66. doi:10.1007/s12020-009-9176-0

14. De Lignieres B. Effects of progestogens on the postmenopausal breast. Climacteric. 2002;5:229-35. doi.org/10.1080/cmt.5. 3.229.235

15. Soderqvist G, von Schoultz B, Tani E. Estrogen and progesterone receptor content in breast epithelial cells from healthy 
women during the menstrual cycle. Am J Obstet Gynecol. 1993;168:874-9. doi.org/10.1016/ S0002-93788(12)90837-6

16. Malet C, Spritzer P, Guillaumin D, Kuttenn F. Progesterone effect on cell growth, ultrastructural aspect and estradiol receptors of normal human breast epithelial (HBE) cells in culture. J Steroid Biochem Mol Biol. 2000 June 1;73(3-4):171-81. PMID:10925217

17. Micheli A, Muti P, Secreto G, Krogh V, Meneghini E, Venturelli E, Sieri S, Pala V, Berrino F. Endogenous sex hormones and subsequent breast cancer in premenopausal women. Int J Cancer. 2004;122(12);312-8. doi.org/10.1002/ijc.20403

18. Lori CS, Christie RB, Jennifer AD, et al. Selected estrogen receptor and androgen receptor gene polymorphisms in relation to risk of breast cancer and fibrocystic breast conditions among Chinese women. Cancer Epidemiol. 2011;35(1):48-55. doi: 10.1016/j.canep.2010.08.005

19. Rohan TE, Negassa A, Chlebowski RT, et al. Estrogen plus progestin and risk of benign proliferative breast disease. Cancer Epidemiol Biomarkers Prev. 2008;17(9):2337-43. doi: 10.1158/1055-9965.EPI-08-0380

20. Baer HJ, Schnitt SJ, Connolly JL, Byrne C, Willett WC, Rosner B, Colditz GA. Early life factors and incidence of prolifera- tive benign breast disease. Cancer Epidemiol Biomarkers. 2005;14(12):2889-97.

doi.10.1158/1055-9965.EPI-05-0525

21. Sitruk-Ware R, Claier F, Sterkers N, Ulmann A, Mauvais-Jarvis P. Prolactin secretion in benign breast diseases. Gynecol Endocrinol. 1987;1(2):195-200. PMID:3140581

22. Walsh PV, Bulbrook RD, Stell PM, Wang DY, McDicken IW, George WD. Serum progesterone concentration during the luteal phase in women with benign breast disease. Eur J Cancer Clin Oncol. 1984;20(11):1339-43. doi.org./101016/0277-5379(84)90051-8

23. Khalid Rida Murshid. A review of mastalgia in patients with fibrocystic breast changes and the non-surgical treatment options. J Taibah Univ Med Sci. 2011;6(1):1-18. doi.org/10.1016/S1658-3612(11)70151-2

24. Ayers JW, Gidwani GP. The "luteal breast": hormonal and sonographic investigation of benign breast disease in patients with cyclic mastalgia. Fertil Steril. 1983;40(6):779-84. doi: https://doi.org/10.1016/S0015-0282(16)47479-0

25. Gorins A, Cordray JP. Hormonal profile of benign breast disease and premenstrual mastodynia. Eur J Gynaecol Oncol. 1984;5(1):1-10. PMID:669804

Sažetak

\section{ULOGA OMJERA E2/P U ETIOLOGIJI FIROCISTIČNE BOLESTI DOJKE, MASTALGIJE I MASTODINIJE}

\section{Brkic, S. Vujovic, M. Ivović, M. Tančić Gajić, Lj. Marina, M. Franić Ivanišević i D. Franić}

Namjera rada je bila ispitati ulogu odnosa estradiola i progesterona za vrijeme lutealne faze ciklusa u pojavljivanju fibrocistične bolesti dojke (FBD). Koncentracija odnosa estradiol/progesteron je bila mjerena u skupini žena s FBD ( $\mathrm{n}=50$ ) (studijska skupina) i u kontrolnoj skupini žena bez FBD ( $\mathrm{n}=40)$ (kontrolna skupina). Sve su žene imale redovite ovulacijske cikluse. Krvni uzorci estradiola (E2), progesterona (P) i prolaktina određivali su se u 8 h ujutro 21. i 24. dana menstruacijskog cikusa. Određivanje značajnosti mastalgije i mastodinije bila je ispitana upitnikom da/ne. Dijagnoza FBD je bila potvrđena ultrazvukom dojke (veličina i broj jednostavnih cista). U kontrolnoj skupini smanjen odnos E2/P zabilježen je od 21. do 24. dana ciklusa (od 14,8 $\pm 11,5 \mathrm{pg} / \mathrm{mL}$ do $9,1 \pm 6,1 \mathrm{pg} / \mathrm{mL}$; p<0,05), za razliku od žena studijske skupine gdje ta promjena nije bila zapažena. Čak i mala promjena odnosa E2/P može doprinijeti nastanku FBD s kliničkim manifestacijama mastalgije i mastodinije.

Ključne riječi: Estradiol; Progesteron; Fibrocistična bolest dojke; Luteinska faza 